\title{
170 Years of Chemistry at the University of Geneva, 1800-1970
}

\author{
Jonas Hauert*
}

\begin{abstract}
On the occasion of the 450th anniversary of the Académie et Université de Genève, a historical account of the developments of chemistry in Geneva from its beginning in the late 18th century to the present time is given.
\end{abstract}

Keywords: Ecole de Chimie - Graebe, C. · History of chemistry at the University of Geneva - Meyer, K. H. · Pictet, A. · Section de Chimie · Tingry, P.-F.

\section{Introduction}

In 1802, the Rector Henri Boissier introduced chemistry as a subject of its own at the Académie de Genève, the school that would later become the Université de Genève. This date marked the beginning of the growth and prosperity of chemistry in Calvin's city. During three distinct periods, through difficult as well as productive times, Geneva's chemists gradually established the reputation of their university as a world-class teaching and research centre. Whereas from 1802 to 1872 chemistry was still largely practiced by amateurs and followed only by a handful of students, the construction of the Ecole de Chimie on the Boulevard des Philosophes in 1879 opened a golden era for chemistry organic chemistry in particular - that lasted until the retirement of Amé Pictet and the crisis of the 1930s. Starting in the 1940s, with an ever-growing number of enrolled students, the number of professors and specialties at the school of chemistry increased likewise, at first in the by then inadequate and decrepit laboratories, until it culminated in the creation of today's Section de Chimie and the inauguration of the new premises on the river Arve in 1970. Each of these eras was marked by places, teachers, researchers and students that reflected the specificities of

${ }^{\star}$ Correspondence: J. Hauert Department of General History University of Geneva

Rue Saint-Ours 5

$\mathrm{CH}-1205$ Geneva their times, as this historical overview will try to demonstrate.

\section{Chemistry in Geneva in the Late 18th Century}

Before 1802, natural sciences were not welcome in the Académie de Genève. Their late introduction was not a consequence of the lack of interest of Geneva's citizens for these sciences. On the contrary, the will to establish specialized chairs at the Academy existed well before 1802. However, the activities of the Academy prevented their creation up to the early 19th century. From its foundation by John Calvin in 1559 to the revolutionary struggles of the late 18th century the Academy of Geneva was controlled by the Vénérable Compagnie des Pasteurs, the ecclesiastic body in charge of education. These pastors made sure that the Academy of Geneva was first and foremost dedicated to the study of theology, law and, to a lesser extent, classics and philosophy. Physics and astronomy classes were taught from 1724, but these branches of science were linked to philosophy and subordinated to theology and law. ${ }^{[1]}$

Nevertheless, chemistry did not enter the Academy of Geneva in a hostile context. The reputation of the city as a European scientific centre preceded the creation of chairs in chemistry by at least one century. Names such as Charles Bonnet (1720-1793), Abraham Trembley (1710-1784), Jean Jallabert (1712-1768) or Horace Bénédict de Saussure (1740-1799) gave Geneva an internationally respected aura when it came to the reputation of its savants. The lack of chairs at the Academy was thus in no way a brake on the expansion of sciences in $\mathrm{Ge}$ neva. Thanks to a favourable financial and intellectual environment, the citizens of the republic developed their scientific activities outside of the conservative Academy. ${ }^{[2]}$

The main scientific forums of the late 18 th century were the learned societies such

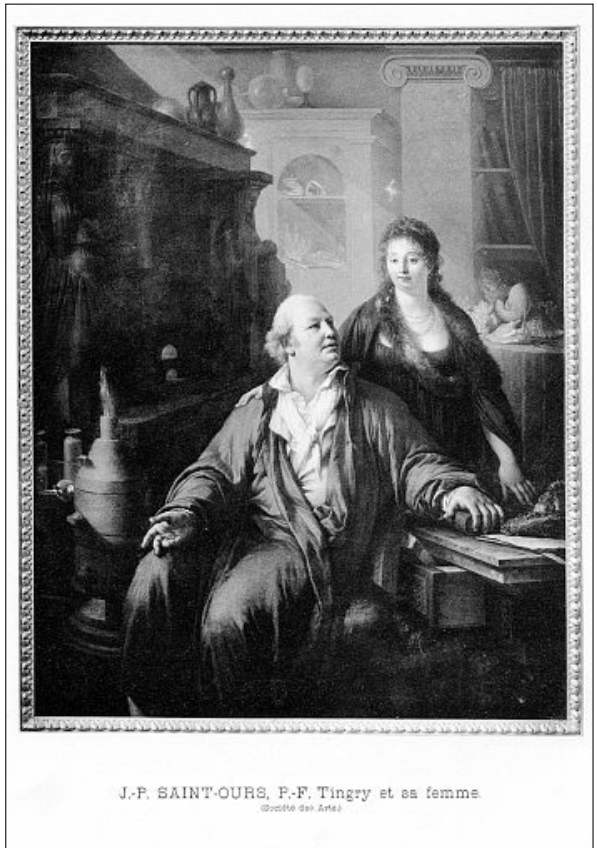

Pierre-François Tingry and his wife

as the Société de Physique et d'Histoire Naturelle or the Société des Arts. The latter, which was founded by Horace-Bénédict de Saussure in 1776, became the first place to offer chemistry classes in Geneva. PierreFrançois Tingry (1743-1821) was responsible for this teaching as soon as the society was established. ${ }^{[3]}$ As a French citizen, Tingry had studied chemistry in Paris before arriving in Geneva in 1770 to work as a pharmacist at Le Royer's pharmacy, at the time a meeting point for local savants. His classes at the Société des Arts, like all his work and inventions, were dedicated to the application of chemistry to the crafts and the industry. Tingry was an adept of the phlogiston theory and the representative of the 18th century applied chemistry. While Lavoisier was establishing the theoretical basis of modern chemistry, in Geneva the discipline remained an empiric endeavour tied to the art of pharmacy and to industrial applications. 


\section{The First Chairs, 1802-1832}

At the end of the 18th century, some local savants called for the creation of chairs dedicated to the natural sciences at the Academy. Following the annexation of Geneva by the revolutionary French troops, the institution became independent from the protestant church. This change rendered possible the creation of a faculty of sciences in 1802 . This foundation was principally spurred by the Rector Henri Boissier (1762-1845) who opened six honorary chairs dedicated to the natural sciences. Three of them were given to chemistry professors: Pierre-François Tingry was hired to teach general chemistry, Henri Boissier awarded himself the chair of chemistry applied to the arts, while CharlesGaspard de la Rive (1770-1834) became professor of pharmaceutical chemistry. This sudden rise of chemistry in Geneva's Academy corresponded to a broader development of scientific teaching throughout Swiss cities and to a revival of the discipline following the work of Lavoisier, Boyle and Priestley. ${ }^{[4]}$

Boissier was the principal actor of the creation of the new chairs. After studying law, he had become professor of classics in the Academy of the late 18th century. Forced into exile during the revolutionary struggles of 1794, he played a crucial role in Geneva's politics as soon as he came back the following year. As for Charles-Gaspard de la Rive, he was a key player of Geneva's scientific world because he hosted well-known scientists in his private laboratory outside of the city. De la Rive was also banned from Geneva in 1794 and went to Edinburgh to study medicine where he completed his $\mathrm{PhD}$ in 1799. After teaching pharmaceutical chemistry until 1819 , he replaced Tingry in the general chemistry chair until 1834 . His reputation was mainly due to his gift as a scientific populariser, even though he published some fundamental articles on electricity and electromagnetism in collaboration with his son Auguste. De la Rive also participated in the political life of the Republic holding the highest function of Premier syndic between 1817 and 1818.[5]

Of the three initial professors, only Charles-Gaspard de la Rive had a longer lasting influence on Geneva's chemistry. Henri Boissier went back to teaching classics and archaeology in 1815, and PierreFrançois Tingry, who died in 1821 , never really lectured chemistry in Geneva. This reduction of the number of chemistry chairs was also linked to the reactionary measures that followed the departure of the French. Furthermore, the auditorium of the Academy was the Chapelle des Macchabées, a 15th century annex to Geneva's cathedral. This was not the ideal place to study and do research in chemistry. Between 1817 and 1834 , private laboratories and local pharmacies were the favoured meeting places of the local chemists. The most famous laboratory of the 1820s was the one of Charles-Gaspard de la Rive. Located in the countryside, it became a centre of European experimental science during the period. Equipped with precision instruments, de la Rive's laboratory seduced famous scientists such as Davy, Ampère, Faraday or Arago.[6]

From 1834, the chemistry laboratory of the Musée Académique became a public alternative to the reputed private laboratories. It was built in the yard of the Musée Académique, an institution founded in 1818 to develop the scientific teachings and exhibit academic collections. ${ }^{[7]}$ The Musée Académique, with its classrooms, its library and its laboratories, functioned as a small faculty until 1872. The 'méchante cuisine', ${ }^{[8]}$ as some called this laboratory, was open to the public every Thursday.

\section{Slow Professionalization, 1832-1872}

Following the death of Charles-Gaspard de la Rive in 1834, Benjamin Delaplanche (1800-1841) took over the chair of general chemistry, a post both men had shared since 1831. Born in Geneva, Delaplanche, an alumnus of the Academy, was not a trained chemist. He held a mathematics diploma from the Ecole polytechnique in Paris and had started his career by teaching algebra at the Ecole des mines in Saint-Étienne before coming back home to Geneva. His class of experimental chemistry was dedicated to theoretical notions as well as practical applications of chemistry to medicine or industry. The course was an overview of chemistry in which students acquired basic notions that could prove useful to the pursuit of other studies such as medicine. ${ }^{[9]}$

Delaplanche was the first professor of chemistry to receive a salary. Tingry's testament stated that, following the death of his wife, a teaching chair of general chemistry should be created with the funds earned through the sale of his domain. The transaction happened in 1831 and the yield from the sale enabled the Academy to pay the young Delaplanche 3500 florins each trimester. ${ }^{[10]}$

During the first half of the 19th century, many famous chemists visited Geneva including Humphry Davy (1778-1829). The British chemist knew Geneva well because of his friend Alexandre Marcet (1770-1822) whom he had met in London in the 1790s. Davy died during a visit to Geneva in 1829 . In memory of her husband's attachment to the city, his widow gave 200 pounds sterling to the Academy. The interest from the sum were used to create the Davy Prize, which was awarded every two years to the student of the Academy who wrote the best memoir in chemistry or physics. ${ }^{[11]}$
Following the untimely death of Delaplanche in 1841, Jean-Charles Galissard de Marignac (1817-1894) took over the chemistry chair. Marignac was born in Geneva, where his uncle Elie le Royer owned a pharmacy. He acquainted himself with chemistry and local chemists in his uncle's shop before entering the Academy. He soon left for Paris and its Ecole polytechnique from which he graduated summa cum laude in 1837 . He then attended Ecole des mines in Paris until 1839. After a short stay in Liebig's laboratory, he briefly worked at the Manufacture nationale de Sèvres. He came back to Geneva in 1841 to become professor of chemistry at the young age of 24 . Marignac was alone in charge of chemistry at the Academy for more than 35 years. $\mathrm{He}$ distinguished himself from his predecessors because he was a chemist whose qualities as a researcher were as important as his teaching skills. Marignac devoted most of his energy to his own research on the atomic weight of elements, earning an international reputation (see article by A. Williams, this issue). Like Berzelius, Stas or Dumas, he participated in the classification efforts of the 19th century. Between 1842 and 1883, Marignac determined the atomic weight of 28 elements. After his retirement in 1878, he even discovered two elements, gadolinium and ytterbium. This solitary savant generally worked in his own laboratory without an assistant. [12]

Amé Pictet, who followed his last chemistry classes, remembered Marignac as a fine man though not overly cheerful. However, according to Pictet, his classes deserved praise because of their clarity and precision that rendered the matter taught easy to understand. Marignac was not an important public figure in Geneva. A discreet loner, he feared "every honorific position", ${ }^{[13]}$ in Emile Ador's words.

It was the work of Louis Michaud, the Academy's laboratory assistant, which made chemistry popular in Geneva in the second half of the 19th century. Michaud gave classes of domestic applied chemistry to the women of Geneva as well as "amusing and instructive" [14] lessons of chemistry with experiments to youths between 12 and 15 years old. He published books of these classes that had some success. His enterprise of popularization was rewarded in 1856 with the silver medal of the Société d'Utilité Publique. Michaud's name became a guarantee of quality and it could be found on advertisements for foodstuffs published in the Journal de Genève during the 1860s. In parallel, Michaud was in charge of the Academy's chemistry laboratory. Amé Pictet, who studied under him, recalled that the students "did large precipitates, filtered and dried, about which not much explanation was given".[15]

From the beginning of the 19th century to the 1870 s, the Académie de Genève was 
relatively small, even for Swiss standards. 154 students were regularly registered in 1814 , only marginally more by 1832 . The highest number of students was reached in 1846 with 289 young men enrolled, and it dropped to fewer than a hundred in the $1850 \mathrm{~s}$. The proportion of students in sciences was low. Between 1836 and 1846, only 91 bachelors in sciences were awarded against 250 in arts. The young men from Geneva studied with other confederates as well as with some of their French neighbours. Between 1798 and 1873, almost 2500 foreign students came to Geneva's Academy; half of them were French. ${ }^{[1,2]}$ In the second half of the 19th century, the Academy trained more and more chemists who were hired to control the quality of materials and foodstuffs. The second industrial revolution needed skilled engineers and the profession of chemist became increasingly recognized. ${ }^{[16]}$ Even if the end of the period was favourable to a certain professionalization of chemistry, the discipline remained dominated by amateur professors, often born in the big families of the city. Rather than a career of itself, chemistry was an ancillary science studied by engineers, physicians or pharmacists. During the first third of the 19th century, adequate academic installations such as laboratories were lacking and chemistry was generally practiced outside the walls of the Academy.

\section{The Golden Age of the Ecole de Chimie, 1873-1932}

In 1873 , the year in which the modern University was founded under the auspices of its first Rector Carl Vogt, himself professor of geology, a golden age for chemistry in Geneva began. Benefiting from an era of material prosperity and helped along by the political authorities, it imposed itself as the main section of the Faculty of Sciences. The chemical industry also played a key role in this process of affirmation because towards the end of the century it was in need of more and more skilled professionals. At the national level, between 1870 and 1920, the number of workers in the chemical industry rose from 1100 to 16800 . This growth was exponential, doubling alone between 1910 and 1920 from 8300 to 16800 . This quantitative expansion was associated to qualitative progress. In the 1880 s, the industry shifted its focus to the production of superior quality colouring agents and dyes that required the knowledge of top-class researchers. ${ }^{[17]}$ The doors of a dynamic industry were thus wide open to the Swiss chemistry students of the late 19th century, and the Swiss universities had to reform their chemistry teaching fundamentally in order to answer the call of the chemical industry.

As a consequence of the affirmation of the chemical industry, the profession of chemist gained a new social status. Advertisers from the period relied on the mention of chemists to boast the quality of their products. It became respectable to become a chemist. In the 1870s, Amé Pictet's father considered that the interest of his son for chemistry was a good thing in view of the development of this industry. ${ }^{[15]}$ The success of chemistry was linked to the success of sciences in general. They were considered to be important vectors of progress. The life of the Belle Époque was turned upside down by technologies such as antisepsis or railroads, which originated in the work of scientists and engineers. In the late 1870 s, with a slight delay compared to its German neighbours, the University of Geneva started to feed "the army of chemists" ${ }^{[16]}$ which was growing all over Europe.

The development of medical and scientific teaching and the foundation of the University of Geneva were also supported by the political will of the local radical leaders. These men wanted to transform the Academy that was considered to be a conservative stronghold. In the 1860 s, they decided to align the institution on the model of German universities. The project to transform the old Academy into a brand new university with the creation of a faculty of medicine eventually took place between 1872 and 1876 .

With the creation of the University of Geneva and its medical school, it became necessary to develop the teaching of chemistry. In 1873, Emile Ador (1845-1920) and Denys Monnier (1834-1898) started to lecture chemistry at the University. Whereas Marignac continued to give classes on inorganic chemistry and mineralogy, Denys Monnier was responsible for a course on biological chemistry while Emile Ador introduced modern organic chemistry to the University of Geneva.

Monnier was born in Geneva. He had studied in his hometown as well as in Strasbourg before opening a pharmacy in Nyon in 1859 . When the University of Geneva was founded, he became Carl Vogt's assistant. He taught biological chemistry for the students of pharmacy before becoming professor of pharmaceutical, biological and analytical chemistry in 1879. As for Emile Ador, he was also born in Geneva. He completed his doctorate at the University of Zurich in 1872 before starting to teach organic chemistry in Geneva in 1873. Ador, Marignac's son-inlaw, was the first representative of the new organic chemistry at the Academy.

Geneva's chemistry grew rapidly following the foundation of the University. This success revealed the inadequacy of the available infrastructures. Dark and dangerous, the new laboratories of the basement of the University were incompatible with the discipline. Even though attendance at the laboratory classes was compulsory for the students of chemistry, they rarely had the chance to do experiments themselves because of the very limited bench space.

For these reasons, the Conseil d'Etat launched the idea of an Ecole de Chimie in 1875. The projected building was intended "to give a new shine" [18] to chemistry at the University. This undertaking was part of the politics of systematic modernization requested by Carl Vogt. Denys Monnier, Vogt's friend and assistant, and the architect Henri Charles Bourrit proposed to build the new Ecole de Chimie on the model of Bonn's school of chemistry. Their plan was accepted and, in 1879, the Ecole de Chimie de l'Université de Genève on the Boulevard des Philosophes opened its doors to the public. Its elegant architecture, its size and the height of its chimney, as well as the technological innovations of the new installations impressed its contemporaries. The organic chemistry and biological chemistry laboratories shared the ground floor. Above them, the school had a large lecture hall for 130 students, a smaller one with 60 seats and a small classroom for privat-docents. A library for chemistry was founded not long after the opening of the building with the help of the Société auxiliaire des Sciences et des Arts.

In 1879, with its own building, chemistry became the main discipline taught at the Faculty of Sciences. Future chemists, physicists, pharmacists or physicians had to attend the classes of Carl Graebe (1841-1927), the newly appointed professor of general chemistry. Graebe, a German specialist in organic chemistry, had replaced Marignac in 1878. Born in Frankfurt am Main, Graebe had studied at the Polytechnicum of Karlsruhe and at the University of Heidelberg where he completed his doctorate under Bunsen in 1862. His professional career started in industry. However, after a severe intoxication, he first went back to the University of Heidelberg and then moved to Berlin to become one of Baeyer's assistants. In 1868, his scientific work earned international recognition when he synthesized alizarin with the help of Carl Liebermann. This colouring agent quickly replaced madder in the textile industry, making Graebe famous. The University of Leipzig recruited him as a professor in 1869. Graebe was a specialist of colouring agents and polycyclic aromatic hydrocarbons. In the first half of the 1870 s, he suffered from a depression. In 1876, he moved to Switzerland to be treated in $\mathrm{Zu}$ rich. While living in the city, he worked as a visiting professor at the local University. He was still there when Marignac left the University of Geneva and Emile Ador, who knew Graebe from Berlin, proposed his name to the Conseil d'Etat. ${ }^{[15]}$

At the Ecole de Chimie, Graebe gave five hours of general chemistry, divided between inorganic chemistry in the winter and organic chemistry in the summer. German became the main language used at the 


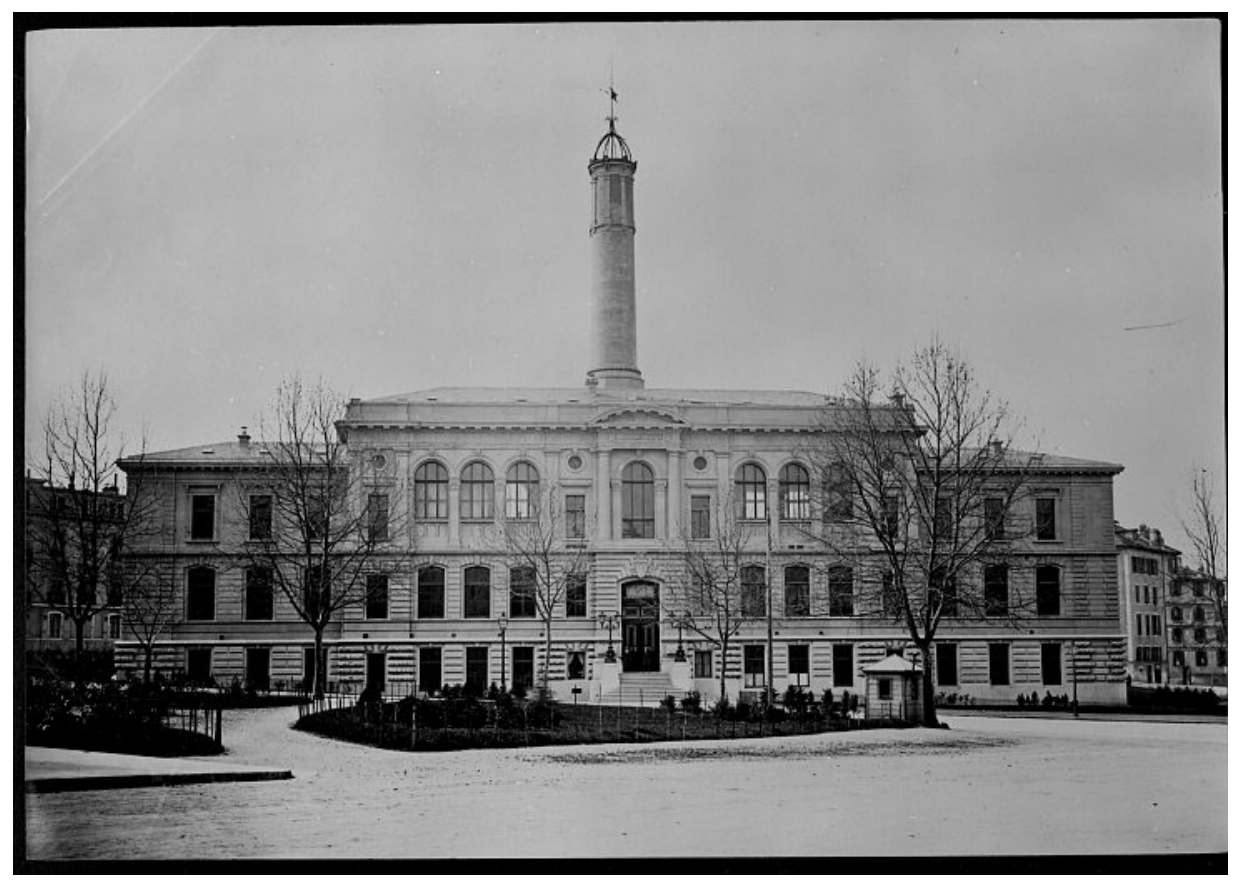

The Ecole de Chimie, Boulevard des Philosophes

Ecole de Chimie. Graebe spoke French with difficulty and a strong accent. However, his passion for teaching was enough to captivate his audience. The hiring of the famous Graebe brought many Germanspeaking students and researchers to $\mathrm{Ge}-$ neva. Graebe's laboratory was a very active place as more than 400 publications came out of it during his tenure. Nostalgic of his hometown, Graebe left Switzerland in 1906. The professor of general chemistry never really felt at home in Geneva and he personally did not publish any serious work during this period at the University.

The hiring of Graebe was one of the signs that chemistry at the University of Geneva was attempting to emulate its German sister institutions. As a result of the scientific domination of Germany and the presence of men such as Carl Vogt and Carl
Graebe, Geneva's scientists of the turn of the century oriented themselves towards the German Empire. Yet, the advent of WWI marked a rupture with the dominant German academic model. The dissociation was not only conceptual; there were real tensions between Germany and the University of Geneva in the mid-1910s. Because some students and professors displayed public hostility to some of the actions of the German troops, the University was blacklisted by a number of German gymnasia. ${ }^{[19]}$ Furthermore, the links between German chemists and those of Geneva were reduced by the departure of numerous German students forced to go back home to serve their country.

Despite its proximity to German science, the University of Geneva still heavily relied on its own alumni to find new professors.
Physical chemistry began to develop around Philippe-Auguste Guye (1862-1922). Born in Champvent in the Canton de Vaud, the older brother of physicist Charles-Eugène Guye followed all his studies at the University of Geneva and completed his $\mathrm{PhD}$ in 1884. After having been Graebe's assistant between 1885 and 1886, he left for Paris to study physical chemistry at the Ecole pratique des hautes études and the Sorbonne. His promising works persuaded the Faculty of Sciences to create an extraordinary chair of theoretical and technical chemistry for him in 1892. During his career, Guye worked on luminous activity, on the quantitative correlation between rotational power and the structure of light, on isomers and on the electrochemical synthesis of nitric acid. He was active in the development of his specialty by founding and editing the Journal de chimie physique between 1903 and 1922. From 1917 to 1920, he became president of the Swiss Chemical Society.

With Amé Pictet (1857-1937), another young local scientist was emerging at the same time as Guye. In 1898, Pictet, another Graebe assistant, replaced Denys Monnier as the professor of pharmaceutical and biological chemistry. Born in Geneva, Amé Pictet was part of a well-known family of the city whose members included the physicists Marc-Auguste Pictet (17521825) and Raoul Pictet (1846-1929). As a student in Geneva, Amé Pictet followed with interest the last classes of Marignac. Because his father wanted Amé to become an engineer, he enrolled the young man at the Polytechnicum of Dresden. After completing his degree, Pictet started a $\mathrm{PhD}$ thesis under one of Kékulé's assistant in Bonn. He finished his work on tartaric esters in Geneva under Graebe's direction in 1881 before leaving for Wurtz's laboratory in Paris. Back in Geneva in 1884, Pictet gave a course on aromatic compounds as a privat-docent until 1888. Because of his
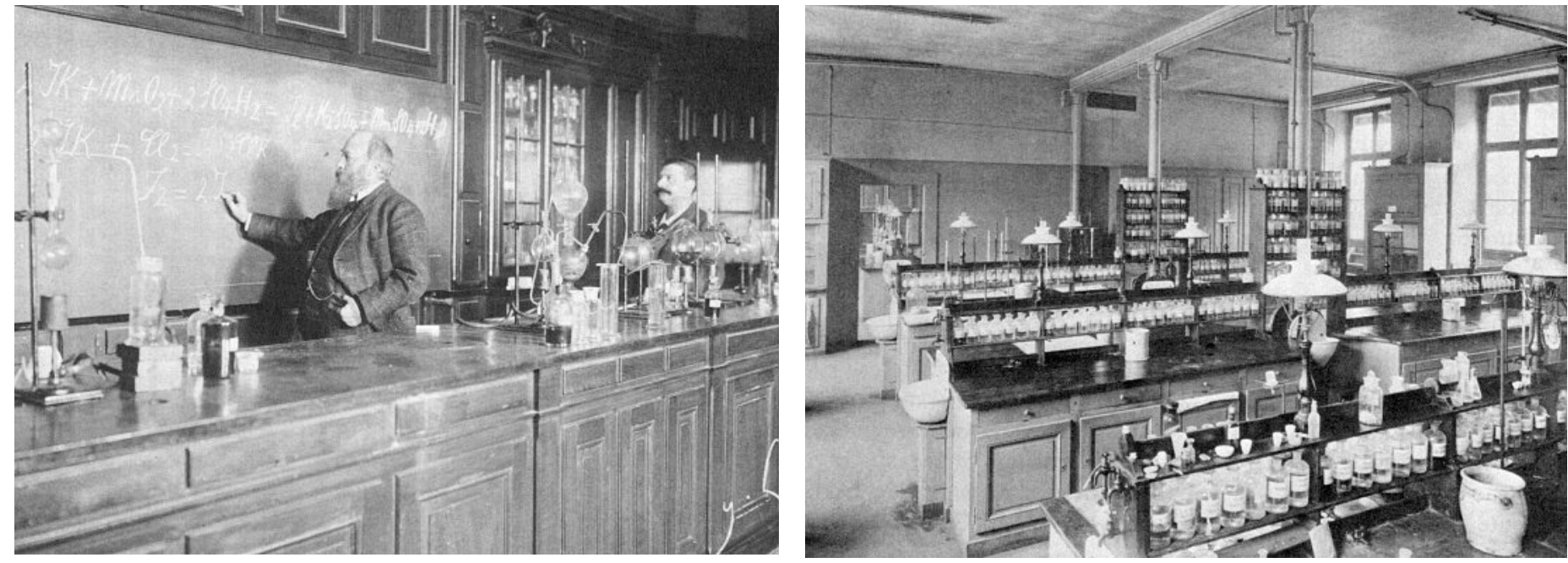


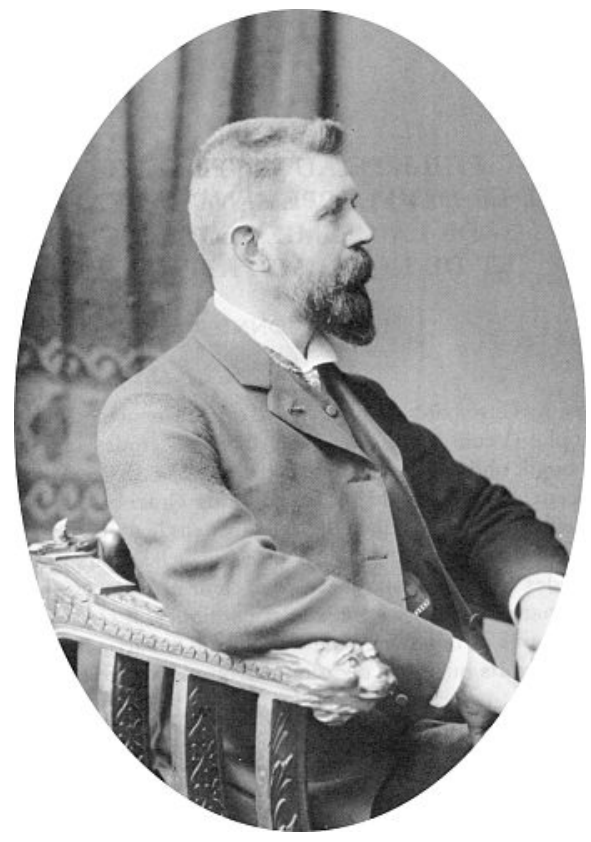

Philippe-Auguste Guye

low salary, he then left to work as a highschool teacher and published a book on alkaloids that became an immediate success.

In 1894, Pictet came back to the University to assist Graebe and his numerous students. He also gave classes on aromatic compounds and alkaloids between 1896 and 1899. In March 1899, Amé Pictet was appointed to the chair of pharmaceutical chemistry. The seven years he spent at this position were very prolific for his research. Because the teaching workload was minimal, Amé Pictet had time to work on his own line of investigation. During these years, he completed the synthesis of nicotine and kept on working and giving classes on aromatic compounds. He had three official assistants during this period, Wilhelm Habel, Otto Spindler and Arnold Rotschy, as well as five personal assistants. Almost one hundred students frequented his laboratory of pharmaceutical chemistry between 1899 and 1906. ${ }^{[15]}$

In 1906, because of Graebe's failure to integrate into Geneva's society, his successor was chosen between the local talents, Pictet and Guye. In July, Pictet was designated to replace Graebe while the University promised Guye that it would promote his chair to the level of Pictet's chair. The course of general chemistry that Pictet inherited from Graebe was the most important of the Faculty of Sciences. The number of students attending these classes varied between 200 and 300 annually until WWI. Pictet lamented the imbalance favouring inorganic chemistry over organic chemistry that forced him to refresh his knowledge of the former. ${ }^{[15]}$

While Pictet was in charge of the main chair of chemistry until the early 1930s, the

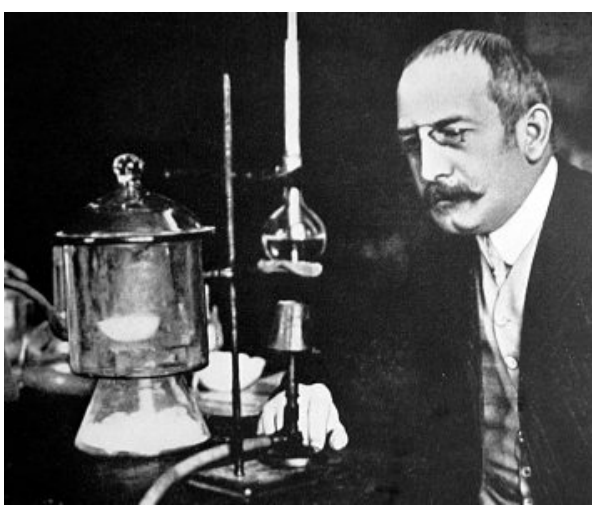

Amé Pictet

other domains of this science carried on expanding. From 1900 to 1932, Louis Duparc (1866-1933) was in charge of analytical chemistry, mineralogy and petrography and taught these disciplines to the future chemical engineers. He worked with Alfred Monnier until 1917 and Paul Wenger (18881962) from 1918 onwards. Born in Geneva, Wenger had completed studies of physics at the University with his $\mathrm{PhD}$ in 1911.

In 1918, Emile Briner (1879-1965), Guye's assistant, became professor of special technical chemistry. He was in charge of the training of the candidates for the diploma of chemical engineering. Born in Carouge in 1879, Briner had studied sciences at the University of Geneva and completed his $\mathrm{PhD}$ in 1902. Before his appointment, he had studied in Paris and worked as a privat-docent both in Bern and Geneva.

For economic reasons, some of the teaching was merged after WWI. In 1923, a commission proposed to dissolve the Ecole de Pharmacie following the retirement of its main professor Louis Chavanne. However, under the pressure of the leaving professor, the chair was retained, but its research quarters were integrated into Amé Pictet's laboratory. Such a fusion was also necessary because of the low number of students of the 1920s. Paul-Emile Cherbuliez. (1891-1985), Pictet's first assistant, was nominated extraordinary professor of pharmaceutical chemistry in 1925. Cherbuliez was born in Mulhouse and had obtained a diploma of chemical engineering from the ETHZ in 1913 before completing his doctorate in 1917 and working as an assistant for Pictet until 1925. A very active scientist, Cherbuliez was known for his involvement as the editor of Helvetia Chimica Acta between 1948 and 1971.

\section{Students and the Social Life at the Ecole de Chimie}

The creation of the Ecole de Chimie reinforced the contingent of chemists at the University, which, in turn, favoured the

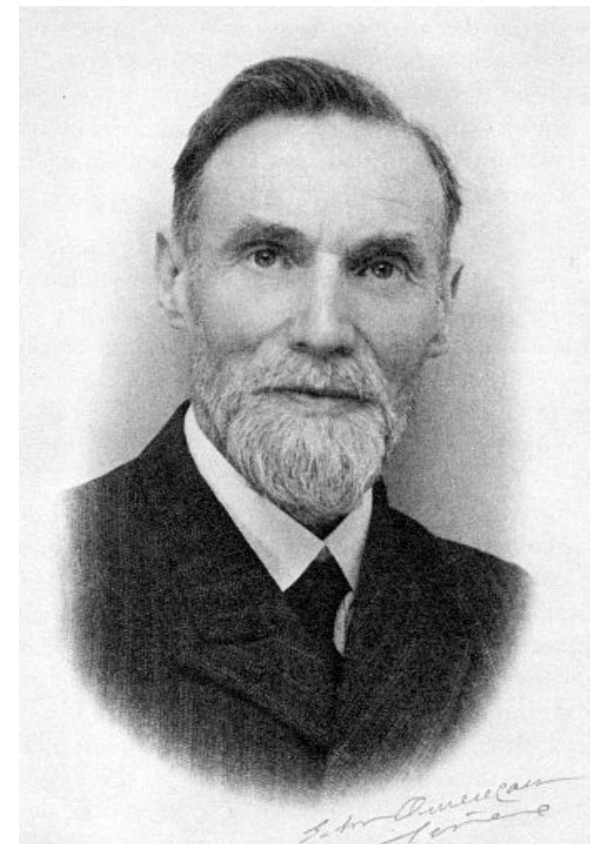

Emile Briner

development of organized social activities between students and professional chemists. The first attempt to unite chemists was launched by Amé Pictet and Eugène Demole (1850-1928), chemist and curator of the Cabinet de Numismatique. In December 1880, they organized a banquet aiming to call together all of Geneva's chemists. 28 people attended the dinner, including a good number of German students. In April 1892, working together, the local chemists - Emile Ador, Alexandre Claparède, Carl Graebe, Philippe-Auguste Guye, Alexandre le Royer, Denys Monnier and Amé Pictetwere able to organize the International Congress of Chemistry in Geneva. The main point discussed during this meeting was the standardization of the nomenclature of organic chemistry, now known as the Geneva nomenclature. The efforts to unite the local chemists were taken up again by the Association des anciens élèves du laboratoire de chimie analytique at the beginning of the 20th century. Its presidents were $A l$ fred Monnier and Louis Duparc. Starting in 1905 , the society organized annual parties that proved to be very popular among students and professors alike. ${ }^{[20]}$ The society was very active until WWI and the end of Geneva's chemistry heydays. The creation of this local society corresponded to a national trend. In 1901, the Swiss Chemical Society was founded and Geneva's chemists became important actors of its history notably through its journal, Helvetia Chimica Acta, which was edited by Amé Pictet during its early years.

The creation of the Faculty of Medicine that marked the foundation of the University of Geneva lured many young men and women to the city. The number 


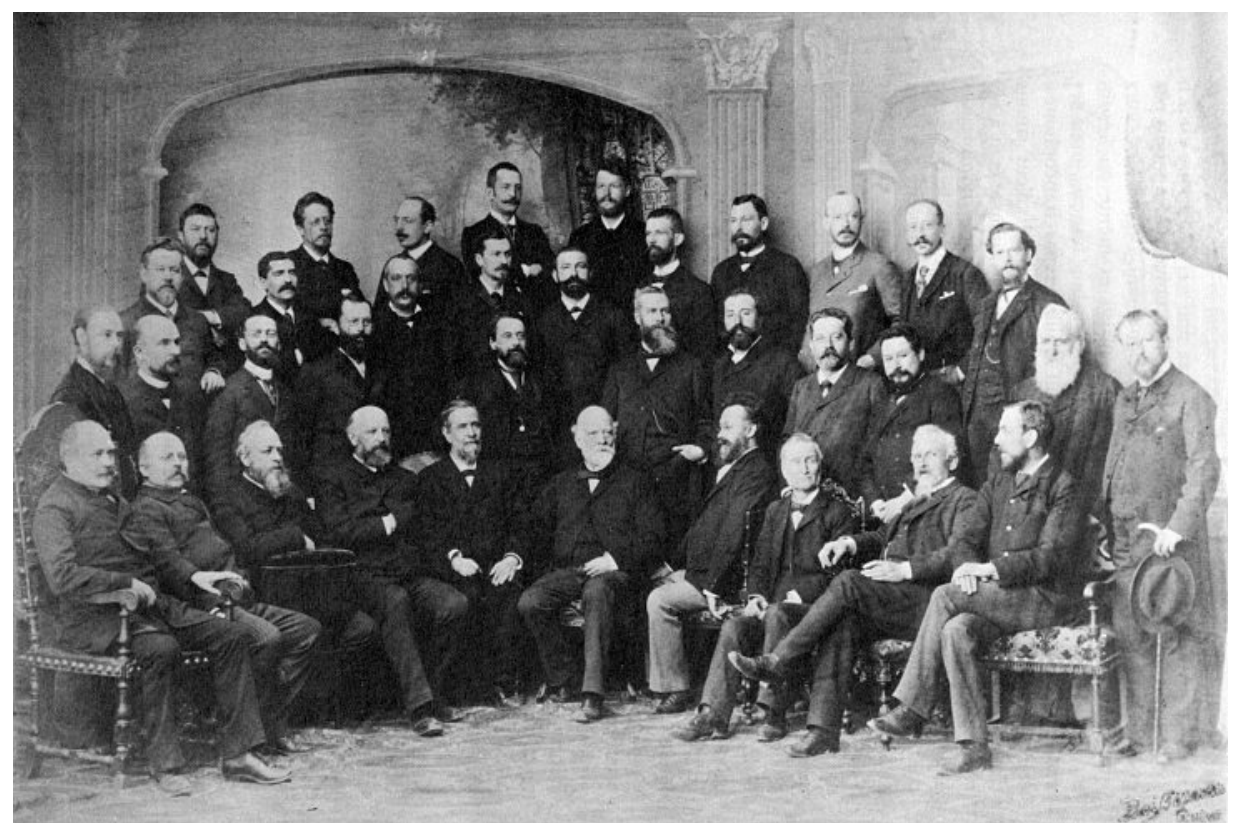

The Geneva Congress on Organic Nomenclature in 1892

of registered students was multiplied by eight in the 1870 s because of the arrival of hundreds of foreign students. Between 1879 and WWI, a strong group of Eastern European students was present in Geneva. In the summer of 1913, 319 students, 222 of them foreigners, were registered at the Faculty of Sciences. Even though most of the international students attended medical school, they also frequented the Ecole de Chimie's classrooms and laboratories. Israel's first president Chaïm Weizman, a privat-docent in chemistry at the time, recalled in his memoirs how the European political tensions of the early 20th century were vivid among the international population of students of the University of Geneva. At the Café Landolt, across from the street, Socialists and Zionists amongst others were discussing the political projects that would mark the 20th century. ${ }^{[21]}$ There were 72 women, mostly Russians, among the registered students of the summer of 1913. Women were increasingly following scientific studies, while generally favouring medicine and humanities. There were two female privat-docents, Irma Goldberg and Ida Welt, studying chemistry at the University of Geneva during the late 1890s. ${ }^{[22]}$

The war abruptly curtailed the flow of foreign students to Geneva. 366 persons followed Amé Pictet's course in the winter of 1914 against only 90 the following year. While the number of foreign students was declining, more and more Swiss students entered the University of Geneva because French or German universities were no longer accessible. In the case of chemistry, the interest of Swiss students was probably also linked to the increasing attraction of the local chemical industry that profited from the weakening of its German counterpart.

\section{New Men, New Domains of Research, 1932-1970}

Because of the limited number of students and the retirement of Amé Pictet, the 1930s were a low point in the history of chemistry at the University of Geneva. During these years, there were fewer students enrolled at the University of Geneva than before WWI. This decline forced the Faculty of Sciences to modify the organization of the chemistry laboratories. In 1933, continuing a process started ten years earlier, all the laboratories of chem-
Chemistry students in 1905 istry were united in a big administrative entity.

At the beginning of the 1930s, two of the chemistry professors were replaced, thus opening a new era for this science at the University of Geneva. Firstly, in 1932, Amé Pictet, who was 75 years old, had to retire. Following his departure, a debate took place at the Faculty of Sciences about the possible separation of organic chemistry from inorganic chemistry. However, financial imperatives favoured the status quo. The German chemist Kurt Meyer (1883-1952) was nominated for the chair of general chemistry on August 1932 . Secondly, Louis Duparc, the professor of mineralogy, petrography and analytical chemistry died suddenly in October 1933. Paul-Eugène Wenger (1888-1962) who had already been professor of the gîtes métallifères since 1918 logically replaced him.

Kurt Heinrich Meyer was born in Dorpat. He had studied medicine and chemistry at the University of Marburg. After spending some time at the London University College, he completed his $\mathrm{PhD}$ at the University of Leipzig in 1907. He then worked as a privat-docent in Baeyer's laboratory in Munich. Meyer was then nominated professor at the University of Munich in 1911. During WWI, he participated in the development of chemical weapons at the Fritz Haber Institute in Berlin. Starting in 1926, he worked for IG Farben. Finally, in 1932, as Germany was sinking into a serious economic and political crisis, Meyer left the country to work at the University of Geneva. During his career, the German chemist led research projects on cellulose and other natural organic compounds of high molecular weight, making him a pioneer of macromolecular chemistry and an important

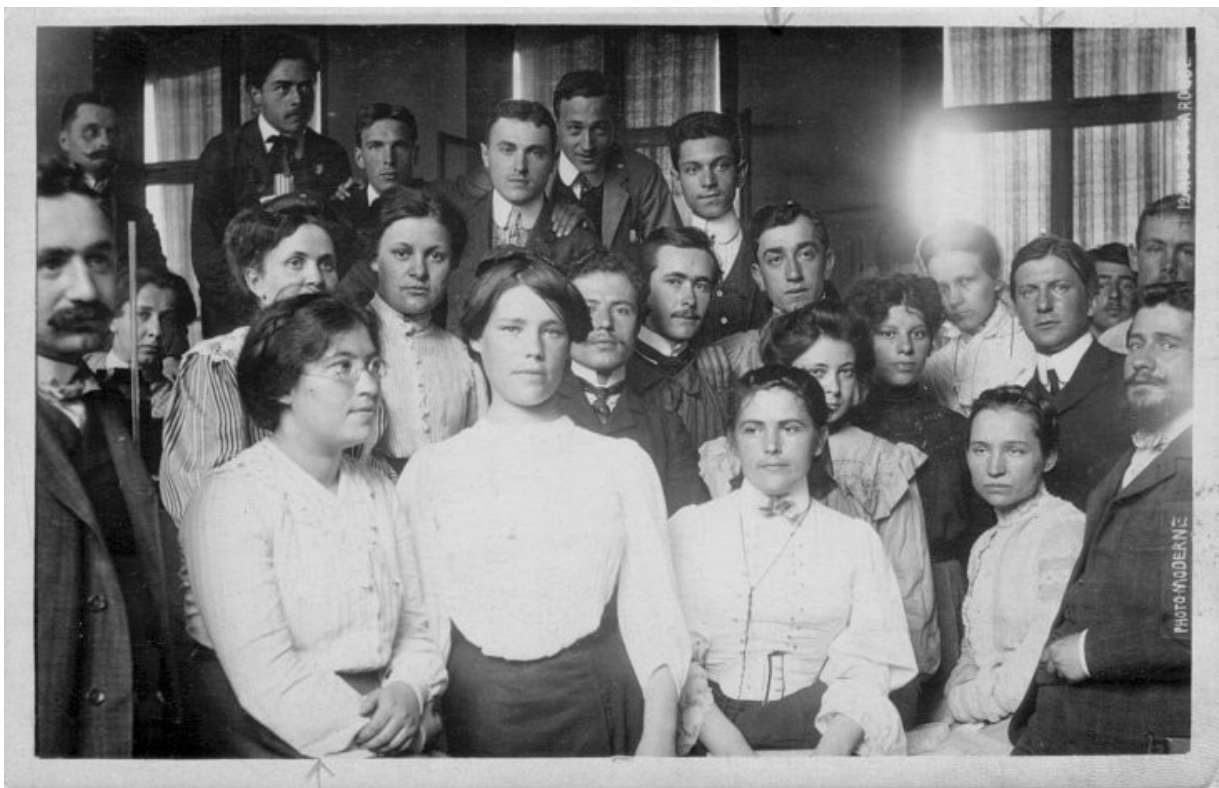




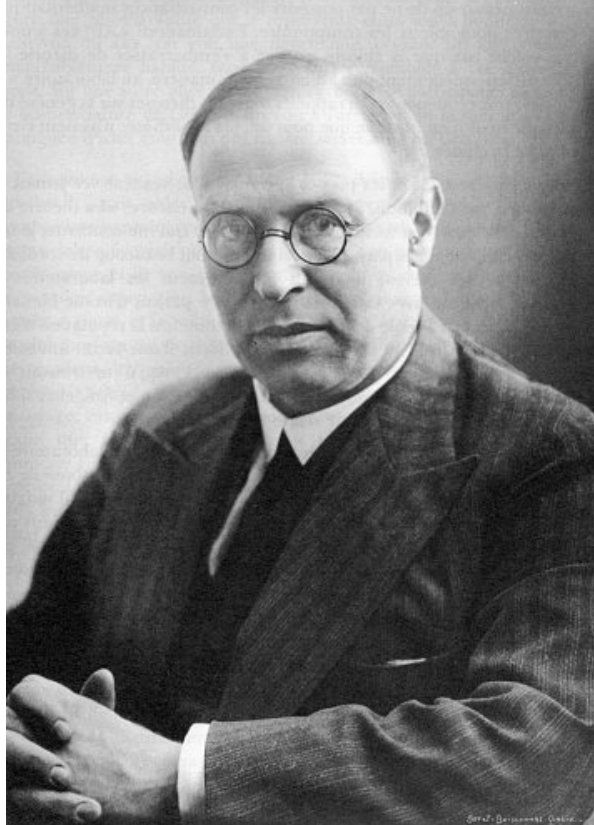

Kurt H. Meyer

player in the creation of the plastic industry and the production of synthetic rubber. $\mathrm{He}$ was among the first chemists to use X-rays and electronic microscopes.

At the end of the 1930s, in order to attract new students, the chemistry curriculum of the University of Geneva was adapted to the needs of the chemical industry. In 1938, the Faculty of Sciences modified its règlement d'études to include two new degrees in chemical sciences and biological chemical sciences. A possibility to specialize in electrochemistry and electrometallurgy was added to the diploma of chemical engineering in order to train chemists for the aluminium industry, which was strongly growing in Switzerland since the late 1880 s thanks to cheap electricity. The decline of the number of students after WWI was only temporary. In the early 1940 s, the number of chemistry students was on the rise again.

As with the preceding war, the beginning of WWII prompted the departure of many foreign students. However, the fall in the number of registered students at the University of Geneva was less drastic than in 1914 because the proportion of international students was much lower in 1939. As was already the case during WWI, movements of solidarity with the victims of the war appeared. For instance, in early 1945, the damaged University of Lyon received chemical material from the University of Geneva.[19]

Between 1939 and 1942, the University's chemistry department was present at the Swiss National Exposition in Zurich as well as at Geneva's fair. However, because of the war, Swiss chemists had much less contact with their foreign counterparts.
The process of editing the International Union of Chemistry's Second Report of the International Committee on New Analytical Reactions and Reagents by Professor Wenger was symptomatic of the isolation of Swiss chemistry. Started in 1938, this project should have been the work of 14 professors from across Europe. WWII reduced this group to three men in 1940 and the further deterioration of the conflict left Wenger and his assistant Roger Duckert alone to complete the task between 1942 and 1945.[23] In these difficult times, Geneva's chemists made an effort to dissociate their science from the fighting raging across Europe. In 1940, at the 150th anniversary of the Société de Physique et d'Histoire naturelle, Professor Briner asserted the loyalty and attachment of the local chemists to their city and their nation as well as their absolute refusal to use their knowledge to serve evil.[24]

International scientific relations immediately resumed at the end of the war. In 1946 and 1947, Wenger and Briner travelled throughout Europe to attend international congresses. The state of the scientific world was different after WWII because Germany had lost its dominant scientific position to the United States. From 1945 to the 1970s, American universities and laboratories served as new models to the European chemists.

Even if the number of students in chemistry was radically increasing in the 1940s, not much changed in the organization of the teaching before 1952. One of the rare innovations between 1945 and 1952 was Emile Cherbuliez's biological chemistry classes that started in 1946. Between the death of Meyer in 1952 and the retirement of Briner in 1954, the Faculty of Sciences completely revised the organization of chemistry teaching and research. In 1952, four new chairs were created eventually opening the possibility of separating organic and inorganic chemistry. Paul Wenger held the chair of inorganic and analytical chemistry. Emile Cherbuliez had tenure of the chair of organic and pharmaceutical chemistry. Théodore Posternak was called to the chair of special biological and organic chemistry, and Denys Monnier became extraordinary professor of special analytical chemistry. Two years later, physical chemistry was separated from electrochemistry following the retirement of Emile Briner. Bernard Susz became professor of physical chemistry while Robert Monnier took over the classes of electrochemistry. All these modifications were the origin of the chemistry section's current division into four distinct departments.

At the same time, the course of general chemistry, which was followed by medical students and biologists, became one of organic chemistry and new courses on chemical thermodynamics, spectrochemistry and numerical problems were introduced. These new classes were representative of the transformations chemistry was undergoing in the 1950s. New instrumental methods enabled researchers to determine complex structures more rapidly. Chemistry was becoming closer to physics, which allowed chemists to explain chemical reactions with the methods of quantum mechanics.

Biological chemistry, which later was renamed biochemistry, began to develop as an independent branch in Geneva only after 1952 and the hiring of Théodore Posternak, followed nine years later by the appointment of Eric A. Stein. In parallel, physical chemistry took an ever-growing place among the laboratory of chemistry thanks, in particular, to the new instruments it provided to all the researchers. Bernard Szuz was in charge of physical chemistry from 1952 until his retirement in 1970 . He worked on the interaction of organic molecules with anti-bases and anhydrous chlorides of boron, aluminium, titanium, zinc and antimony.

\section{Financing Research and Accommodating Students}

After WWII, the financing of scientific research and of the necessary facilities increased dramatically. Before 1960, the Canton was in charge of about $90 \%$ of the University's budget. The remaining $10 \%$ came from private donations or from the Confédération. This situation was not perennial because the University's expenses increased tenfold between the early 1940s and the end of the 1960s.

Part of the capital needed to undertake research came from the Société Académique. Founded in 1888, this society, whose aim is to develop academic life at the University of Geneva, was a financial pillar of research in the institution. In the 1930s, it bestowed large sums of money for the installation of Kurt Meyer's laboratory. It also participated in the purchase of a Steinheil spectrograph and some electric arc furnaces for Emile Briner's laboratory. These instruments - proofs of the Société Académique's role - were of a critical importance to the development of chemistry at the University of Geneva after WWII.

However, the Société Académique could not financially support Geneva's chemical research alone. After 1945, in order to gather much needed resources, the University relied on the generosity of private benefactors. For instance, in 1947, at the level of chemistry, the University's Fonds Général received 100000 CHF from the Swiss Syndicate of Chemistry in liquidation. ${ }^{[25]}$ Alumni or retired collabora- 


\section{General Chemistry}

Pierre-François Tingry

1802-1819

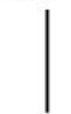

Charles-Gaspard De la Rive

1819-1834<smiles>CCCC</smiles>

Benjamin Delaplanche

1834-1841<smiles>C=CC</smiles>

Jean-Charles Galissard de

Marignac

1841-1878
Pharmaceutical Chemistry

Charles-Gaspard De la Rive 1802-1819

\section{Biological and}

Pharmaceutical Chemistry

Denys Monnier

1873-1898
Chemistry applied to the Arts

Henri Boissier

1802-1815

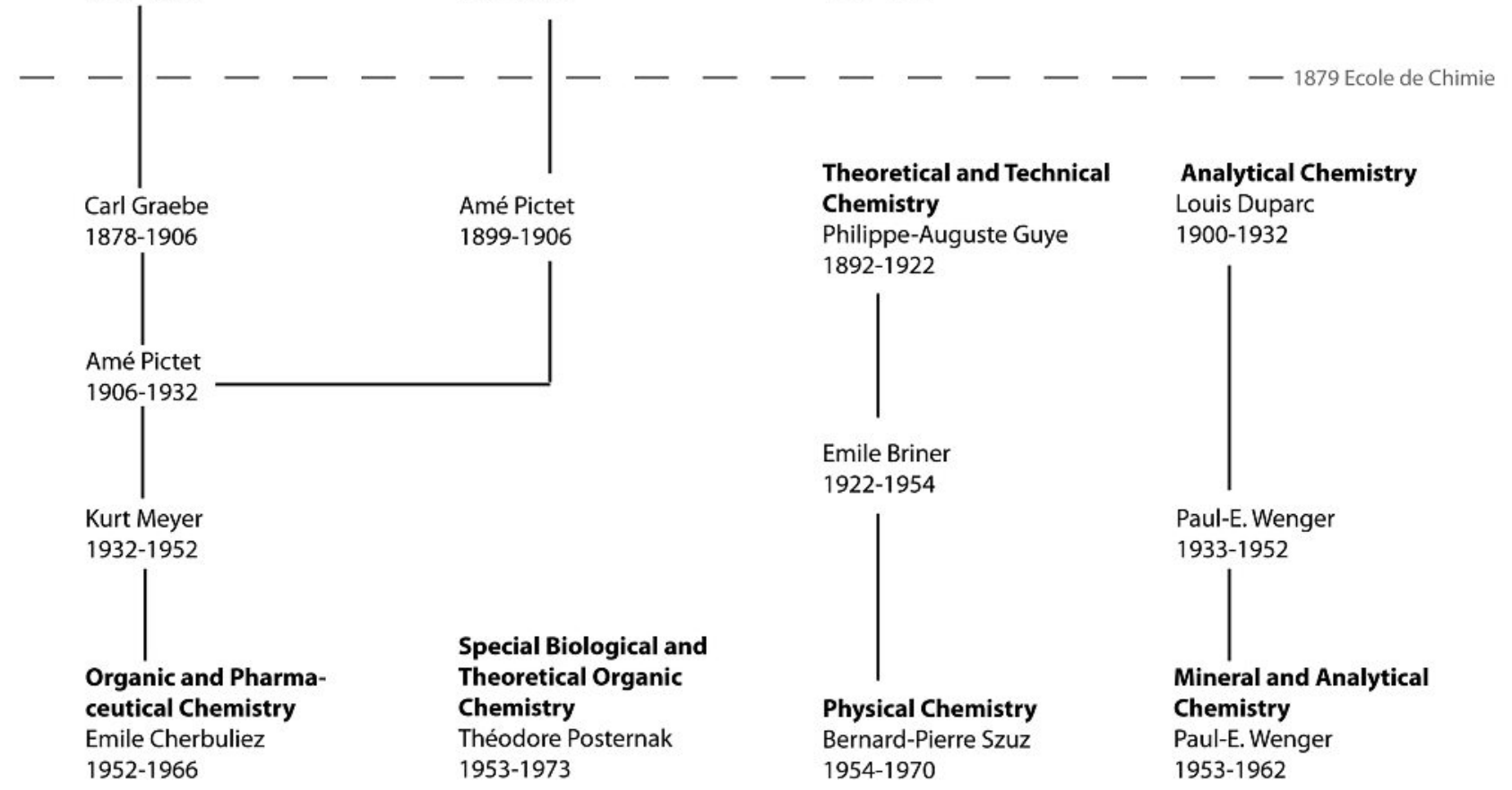

\section{Organic Chemistry}

Emile Ador

1873-1878
Analytical Chemistry

ouis Duparc

Philippe-Auguste Guye

892-1922

Bernard-Pierre Szuz

1954-1970
Paul-E. Wenger

1953-1962

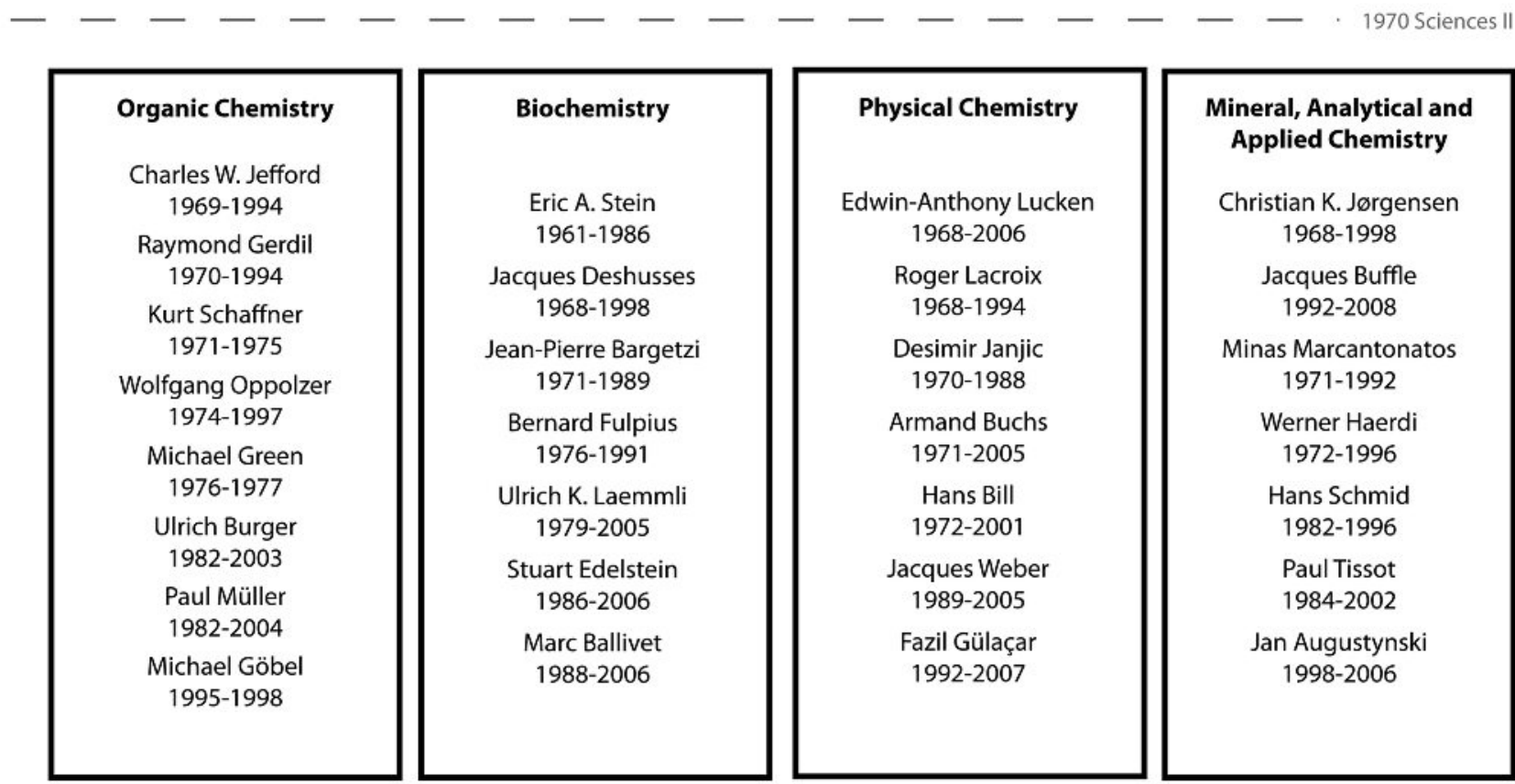


tors also gave money to help finance chemistry at the University of Geneva.

In the 1950s and 1960s, research at the University of Geneva experienced a new impetus following the creation of the Swiss National Science Foundation in 1952. The federal organization of the financing of scientific research enabled Geneva's scholars to access much needed money. Geneva's chemistry was involved in the process of creation of the SNSF. Indeed, Emile Briner participated in this process as the representative of the French-speaking universities. [26]

Starting in the 1940 s, the number of chemistry students constantly increased. Foreign students came back to the University in large numbers. American students, followed by the French, were the most numerous to enrol. In the winter of 1946-1947, more than 2000 students were registered at the University and $42 \%$ of them were foreigners. The following year, $50 \%$ of the 2318 registered students were not from Switzerland.[2] Since 1945, the student body radically changed its composition. Young Americans replaced the Germans. The arrival of these new students coincided with the introduction of new activities, such as team sports, generally associated with Anglo-American colleges. Basketball became very popular in the late 1940s; the chemistry section had a team including American students, which participated in the 1948 University championships. ${ }^{[27]}$ Seemingly trivial, the development of basketball at the University of Geneva was a sign of the academic mutations of the times.

In the 1960s, as a consequence of the increasing number of students and due to the limited size of the laboratories, 300 students of chemistry were sharing 165 places of work. The fusions of the laboratory that took place in the 1920s and 1930s had restricted the number of available places. Many students had to take turns to work in the laboratories. The introduction of a $\mathrm{nu}$ merus clausus in chemistry was even considered because of the state of the Ecole de Chimie.

Since the end of the 1930s, the Ecole de Chimie had displayed its decrepitude. In 1939, an article in the Journal de Genève related that the stone of the building was in such a bad shape that it fell on the heads of the students. ${ }^{[28]}$ During WWII, the principles of an extension of the University including a new school of chemistry were defined, but financial constraints terminated this project before it was really initiated. In 1943, to overcome this lack of space, Professor Meyer managed to find money to raise the central aisle of the Ecole de Chimie. The building was renovated and adapted throughout the 1950s, when more than $145000 \mathrm{CHF}$ were devoted to multiple works.

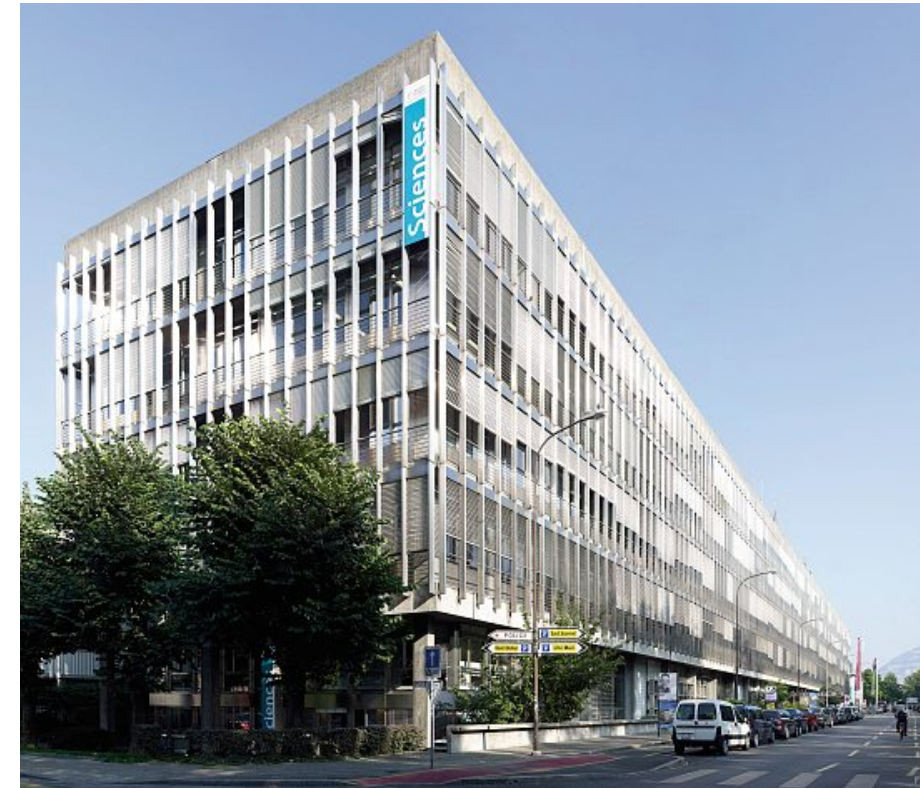

Le bâtiment de Sciences I/ (photo Régis Golay)

The lack of space and the worn laboratories were a recurring problem of the twenty-five years following WWII. The Ecole de Chimie had become inadequate for the practice of modern chemistry. In the early 1960s, like 20 years before, the University asked the Conseil d'Etat to finance a new building to accommodate some of the laboratories of the Faculty of Sciences. In March 1967, the Grand Conseil allotted 21 million CHF for the construction of this building known as Sciences II. The first offices were completed in 1970 and the chemistry laboratories left the old Ecole de Chimie for the banks of the Arve River.

The inauguration of the Sciences II building opened the last era of the history of chemistry at the University of Geneva. With a team of professors of chemistry coming from other Universities and four separate departments, chemistry became a full section of the Faculty of Sciences.

\section{Acknowledgements}

I thank the BGE, Centre d'iconographie genevoise for the permission to reproduce the photos in this article. I also thank Profs F. Walter (Département d'Histoire Générale), S. Matile and A. Hauser (Section de Chimie) for their help.

\section{Received: October 13, 2009}

[1] C. Borgeaud, 'Histoire de l'Université de Genève: L'Académie de Calvin dans l'Université de Napoléon, 1798-1814', Georg, Geneva, 1909, 25.02.1975.

[2] M. Marcacci, 'Histoire de l'Université de Genève, 1559-1986', University of Geneva, Geneva, 1987.

[3] 'Les savants genevois dans l'Europe intellectuelle: du XVIIe au milieu du XIXe siècle', Ed. J. Trembley, Ed. du Journal de Genève, Geneva, 1987.

[4] B. Wojtowiak, 'Histoire de la chimie de l'Antiquité à 1950', Technique et documentation - Lavoisier, Paris, 1984.

[5] 'Les savants genevois dans l'Europe intellectuelle: du XVIIe au milieu du XIXe siècle',
Ed. du Journal de Genève, Geneva, 1987, Ed. J. Trembley.

[6] C. Borgeaud, 'Histoire de l'Université de Genève: L'Académie et l'Université au XIXème siècle 1814-1900', Georg, Geneva, 1934.

[7] J. J. Paschoud, 'Premier rapport sur l'origine et l'accroissement du Musée académique de Genève: fait à l'assemblée des souscripteurs et donateurs de cet établissement, par les membres de son administration, le 9 mars 1820', Geneva, 1820.

[8] Journal de Genève 17.04.1894, 2.

[9] 'Programme du cours de chimie expérimentale: donné au Musée académique en 1831-1832 par MM. les professeurs De la Rive et De la Planche', [n. a.], Geneva, 1831.

[10] 'Arrêté sur l'organisation de la chaire de chimie expérimentale, fondée dans l'Académie de Genève par Mr le Prof. Tingry', [n. a.], Geneva, 1832.

[11] Revue des deux mondes 1830, 3, 85-86.

[12] Centenaire de l'Ecole de Chimie, 1879-1979', University of Geneva, Geneva, 1979.

[13] E. Ador, 'Jean-Charles Galissard de Marignac', [n. a.], Geneva, 1894.

[14] Journal de Genève 04.10.1854, 4.

[15] A. Pictet, 'Souvenirs et travaux d'un chimiste', Ed. de la Baconnière, Neuchâtel, 1941.

[16] D. Knight, H. Kragh, 'The Making of the Chemist: The Social History of Chemistry in Europe, 1789-1914', CUP, Cambridge, 1998.

[17] 'Dictionnaire historique de la Suisse', vol. 3, G. Attinger, Hauterive, 2008.

[18] Journal de Genève 04.06.1876, 1.

[19] P. E. Martin, 'Histoire de l'Université de Genève: L'Université de 1914 à 1956', Georg, Geneva, 1959.

[20] Journal de Genève 22.02.1908, 4.

[21] L. Mysyrowicz, 'Université et révolution: Les étudiants d'Europe Orientale à Genève au temps de Plékhanov et de Lénine', Revue Suisse d'Histoire, p. 514.

[22] CM. R. S. Creese, T. M. Creese, 'Ladies in the laboratory?: American and British women in science, 1800-1900', Royal Society, London, 1998.

[23] Journal de Genève 26.10.1945, 8 and 27.11.1945, 5.

[24] Journal de Genève 19.10.1940, 4.

[25] Journal de Genève 19.06.1947, 1.

[26] A. Fleury, F. Joye, 'Les débuts de la politique de la recherche en Suisse', Droz, Geneva, 2002.

[27] Journal de Genève 20.02.1948, 7.

[28] Journal de Genève 24.03.1939, 6. 